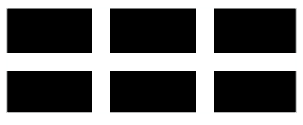

ThE WILLIAM DAVIDSON INSTITUTE

AT THE UNIVERSITY OF MICHIGAN BUSINESS SCHOOL

\title{
Retained State Shareholding in Chinese PLCs: Does Government Ownership Reduce Corporate Value?
}

By: Lihui Tian and Saul Estrin

William Davidson Institute Working Paper Number 750

February 2005 


\title{
Retained State Shareholding in Chinese PLCs: Does Government Ownership Reduce Corporate Value? *
}

By:

\section{Lihui Tian and Saul Estrin}

\begin{abstract}
The role of government shareholding in corporate performance is central to an understanding of China's newly privatized large firms. In this paper, we analyze shareholders as agents that can both harm and benefit companies. We examine the ownership structure of 826 listed corporations and find that government shareholding is surprisingly large. Its effect on corporate value is found to be negative, but non-monotonic. Up to a certain threshold, corporate value decreases as government shareholding stakes increase, but beyond this corporate value begins to increase. We interpret this in terms of ownership concentration and the advantages of government partiality. JEL classification: G32, G34, G15, L33

Key words: government shareholding, corporate governance, China.
\end{abstract}

November 25, 2004

*This paper had benefited from the comments of James Ang, JP Mei, Larry Lang, Mario Nuti, Enrico Perotti, Lawrence Rose, Henri Servaes, Oren Sussman, Eli Talmor, Paolo Volpin and participants of the seminars at the London Business School, Cardiff Business School, Brunel University and Lancaster University as well as the Fortis International Finance Conference. Data collection for this paper would not have been possible without the help of Dr. Yaping Xu from the China Securities Regulatory Commission, Hui Gong from the Genius Co. and Yun Xia from the Hairong Co., Dr Houqi Zhang from the Hua Xia Securities Co. The financial support of the Center for the New and Emerging Markets at the London Business School is acknowledged. Any remaining errors are our own. 


\section{Introduction}

The Chinese economy has performed exceptionally well in the past twenty five years, with GDP more than quadrupling since reforms began in the late 1970s and the economy predicted to overtake that of the United States in terms of purchasing power parity by 2015. The stock market has grown fast and has attracted Morgan Stanley Inc. and other international investors, but some issues which are essential to an understanding of China's reform and its public listed companies (PLCs) have not been well addressed.

China did not follow the reform path favored by transition economies of Central and Eastern Europe, which focused on complete and rapid liberalization, privatization and democratization (see e.g., World Bank, 1996). Rather, China's reform has been constructed to achieve the joint objectives of improved economic efficiency and ensuring that reforms remain acceptable to the Communist Party in power by increasing the economic pie while allocating a share of those additional resources to those in power (Qian, 2003). This approach to reform has been analyzed with respect to market liberalization (see Lau, Qian, and Roland, 2000) and early ownership reform, which relied on the growth of new firms in township-village enterprises (TVEs) (see, e.g., Li, 1996; Chun and Wang, 1994; Che and Qian, 1998). In the past decade, the reform process has extended to the State Owned Enterprise (SOE) sector that still comprises a significant share of industrial output, (see Allen, Qian, and Qian, 2004). The emphasis has been to improve performance by corporatizing the former state owned firms, listing them on China's stock exchanges and selling shares to non-state owners in order to facilitate tougher corporate governance.

The companies now listed on China's stock market are among the most profitable enterprises in China and their business operations and governance structures are modeled on American corporations. However, state ownership still plays a major role. The government is found to be the majority shareholder in 31 percent of Chinese PLCs, and to hold more than 10 percent stakes in 41 percent of PLCs. This is a much higher shareholding than observed in either developed or other emerging markets (see Claessens, Djankov, and Lang, 2000).

Economists generally view government ownership as being detrimental to corporate performance. For example, Shleifer and Vishny (1998) show that private ownership is preferable to state ownership because the government has a "grabbing hand" that extorts firms for the 
benefit of politicians and bureaucrats at the expense of corporate wealth. Estrin and Perotin (1991) argue that, even if the government is not corrupt, the firms under the control of the government shareholder cannot concentrate on profit maximization, because the state has political as well as economic objectives while governance will be weaker. These factors, including the absence of a bankruptcy constraint, are predicted to lead to lower efficiency in state owned firms than privately owned ones. Empirical evidence strongly supports this contention. For example, Megginson and Netter (2001) conclude that "[the weight of empirical research] is now decisively in favor of the proposition that privately owned firms are more efficient and more profitable than otherwise comparable state owned firms.” However, Blanchard and Shleifer (2000) and Qian (2003) suggest that in China government ownership can in fact be helpful, to company performance. Certainly some firms under the control of the Chinese government are well liked by international investors, including Warren Buffet. The positive roles that the government shareholder can play come from preferential commercial treatment as well as governance advantages when state ownership is concentrated. Combining the theory of inefficient government ownership with the Chinese institutional environment leads us to hypothesize that the firms under the control of a private shareholder will perform better than those under the control of the government shareholder. However we go on to argue that there will also be a non-linear relation between corporate performance and government shareholding in China's mixed enterprises, because of the benefits that can be obtained from the government shareholder especially at high levels of state ownership.

In the paper, we examine this hypothesis empirically using a large sample of Chinese PLCs containing 2660 firm-year observations. In particular, we explore the effects of different levels of government shareholding on corporate value. In line with the Western literature, the overall impact of state shareholding on corporate values in China is found to be negative. However, the firms with diffused shareholding structures are found to perform worse than both privately and state owned firms. Hence the relation between corporate value and the size of government shareholdings is found to be non-monotonic; in fact it is U-shaped, with a higher level of corporate value with lower levels of state ownership than with higher ones. That is, when the size of government shareholding is sufficiently large, the effect of government shareholding on corporate performance is marginally positive relative to situations where private and state ownership are more equally balanced. This finding is robust, including to questions of 
reverse causality, and is consistent with the findings from previous work on China that reforms have managed to provide incentives for private agents and the government which lead both to act in ways that enhance efficiency (see Qian, 2003).

In the following section, we set the scene by providing information on the emergence of Chinese PLCs and the Stock Exchanges, including ownership structures. Our hypotheses about the performance of firms as government ownership levels vary are outlined in the third section, and the econometric methods and results including questions of endogeneity in the fourth. We draw conclusions in the fifth section.

\section{Shareholding in Chinese PLCs and the institutional environment}

In this section, we use our data to enrich our understanding of the reform process in the former state owned sector, focusing particularly on retained government ownership. We first present the data set and provide a brief description of the Chinese institutional environment before examining the ownership structures of Chinese PLCs.

\section{A. The data set}

Our data is based on the audited Annual Reports from all PLCs and share price data from the two Stock Exchanges. Taiwan Economic Journal is a leading vendor on Chinese PLCs, but their data contain a large number of missing values and domestic investment bankers and security analysts tend to use the Genius database instead. The Genius database is widely used by the Chinese investors on the stock market. We have constructed a new data set by combining both databases with other complementary sources (see the Appendix). This covers accounting information, the holding stakes of large shareholders, and daily share prices from 1994 to 1998, during which time the regulatory framework was relatively consistent. The 1994 Company Law formally legislates and governs joint-stock companies. In the same year, the China Securities Regulatory Commission also introduced a series of six rules called Contents and Forms of The Information Release by PLCs, which formatted the annual reports. In 1999, a new version of the Company Law was introduced which led to many changes in the information collected. For this reason we do not seek to extend our analysis beyond 1998.

Our data set excludes fund management companies. Their operations are distinctly different from those of industrial firms and the government is not allowed to own them. We also 
exclude firms that do not issue shares to domestic investors so we do not have to use the share prices from the foreign investors market. The data set contains 287 companies in 1994, 311 in 1995, 517 in 1996, 719 in 1997, and 826 in 1998, summing to 2660 firm-year observations in twenty-one industries. The description of corporate features and ownership structures is based on 1998 data.

\section{B. The institutional environment}

Prior to reforms there were virtually no private firms in the Chinese industrial sector. Large enterprises were either fully owned by the state or collectively owned, and usually controlled by a multitude of bureaucrats in central and local government. Enterprises in China before the advent of reform were thus virtually sub-units of various tiers of the government rather than commercial entities in their own right. All financing was paid out of the state budget, the prices of production factors and products were fixed, and the government set production targets. Furthermore, enterprises were required to provide their employees with housing, schooling, and even a funeral service when they died. The incentive problem is illustrated by the fact that managerial pay was not much higher than the wages of workers.

The economic environment for SOEs began to change in the early 1990s (see Qian, 2003), with a clarification of property rights, changes in corporate governance, and the use of commercial modes of operation. The clarification of property rights has often involved recapitalization and partial privatization. ${ }^{1}$ Many former SOEs were restructured to form joint stock companies that have more than one owner. Combining this with a pairing of control rights to residual returns provides owners with an incentive to maximize the value of these enterprises ( $\mathrm{Li}, 1997)$ in an increasingly important sector of the economy. According to figures produced by the National Bureau of Statistics in China in 1999, joint stock companies made up 3.3 percent of the total number of firms in China, but generated 7.3 percent of the industrial GDP and 14.6 percent of profits. Between 1994 and 1998, the number of joint stock companies grew by 28 percent per year and their contribution to the GDP grew by 36 percent per year.

Political control of these firms has been significantly reduced since 1993. In the past, managers were monitored through employee associations and the enterprise branch of the Communist Party, but since 1993 the law has explicitly forbidden the secretaries of the various

\footnotetext{
${ }^{1}$ The Chinese government does not in fact recognize the term "privatization".
} 
branches of the Communist Party to interfere with corporate management. However, the Party and the government can influence the firms through voting rights from its shareholding. In 1994, a formal Company Law was introduced to create a set of modern governance structures. This require firms to be commercially operated under the rule of market competition: for example supply and demand must decide prices; finances must be raised through banks and other creditors; firms must pay dividends to their shareholders; pay back interest and principal to their creditors, and tax to the government. Though China's economy is still characterized by widespread government ownership coupled with weak legal enforcement of the new legislation, we would contend that the SOEs have now become independent commercial entities.

\section{Corporate governance and the stock market}

The 1994 Company Law stipulates that the Board of Directors monitors managers. Directors are de jure elected at a general meeting of shareholders under a one-share-one-vote system. The Board of Directors is usually composed of the delegates of the large shareholders, who can nominate managers to be members of the Board. When the government is the largest shareholder, a former party secretary or a retired bureaucrat is usually assigned to be the chairman of the board.

For example, the government holds 88.6 percent of shares in the firm Qinggong Machinery. The other shareholders in Qinggong Machinery are family investors and some township-village enterprises. The government agent that controls the government's shareholding is the Shanghai Electronics Group (an SOE), which is fully owned by the state and operated like a department of the Shanghai Municipal Government. The mayor of the Shanghai Municipal Government and his management committee, chosen by the central government in Beijing, decide on the appointment of the board of the Shanghai Light Industry Machinery Company Limited. Mr. Zhao Dingzhai was appointed to be both President and General Manager. Other board members include communist party secretaries, union representatives, senior management and other companies, both SOE and legal person. There were no external directors, or directors representing minority shareholders, on the board.

Once elected, the duties of directors include approving annual reports and corporate strategy, appointing a general manager, and monitoring management. There is also a Supervisory Board, whose members are mainly employees. This has inherited the legacy of the employee 
association under planning but its role is purely advisory. The general manager is in charge of the daily operation of the enterprise, with bonuses linked to corporate performance, although the absolute sizes of bonuses are small. The top management team can be shareholders of the company, but these shares cannot be transferred during their tenure and securities laws require that managerial shareholdings be disclosed to the public. In practice, managerial shareholding is miniscule in China, perhaps because stock option schemes have been rare. In our 1998 data set, we find that managers held, on average, only 0.005 percent of the total shares in public listed companies.

The Chinese stock market comprises the Shanghai Securities Exchange (SHSE) and the Shenzhen Stock Exchange (SZSE), which began to operate in December 1990 and July 1991, respectively. There is no fundamental difference between the two in terms of legislation and regulations; they were separated to encourage competition. Table 1 shows that the market has grown rapidly; between 1992 and 1998, market capitalization increased at an average rate of 84.7 percent per year. At the end of 1998, total market capitalization was about a quarter of China's GDP. The number of listed companies grew by 62 percent annually, from 53 PLCs in 1992 to 851 PLCs in 1998. However, the market is still in the early stages of development, as reflected by its high volatility, trading problems, and the threat of policy interventions ${ }^{2}$. [Table 1 here]

\section{Ownership structure of Chinese PLCs}

These Chinese PLCs are usually very young, with an average age of 14 years and a median age of seven years. PLCs are either newly formed or older companies restructured during the period of reform. However, the most striking feature of Chinese PLCs is their ownership structure. The Chinese stock market classifies owners of shares into five groups: state, legal person, employee, tradable-A shares and shares denominated in a foreign currency, all providing equal voting rights. The boundaries between the categories are not always clear; for example institutional shareholders do not own legal-person shares and foreign shareholders do not only own shares denominated in foreign currency. But this is the only currently available

\footnotetext{
${ }^{2}$ At the end of 1998, the turnover rate was 291 percent and the price/earning ratio was 33.4. Moreover, since the legal enforcement of securities legislation in China is weak, insider trading and market manipulation is widespread and frequently reported in the press. To control risks, the government frequently holds policy talks; one on the high $\mathrm{P} / \mathrm{E}$ ratios of the stock market at the end of 1996 brought down the stock index by 10 percent. The market is also segmented: about 60 percent of shares are restricted in terms of their tradability and only 5 percent of shares are allowed to be invested in a foreign currency.
} 
classification system for share ownership (see also Xu and Wang, 1999; Qi, Wu and Zhang, 2000). The three main categories of shareholder are the state, legal persons and tradable A shares, each with around 30 percent of total shares. The state's shareholding is, on average, gradually declining between 1994 and 1998, matched by an increase in the non-tradable holdings of domestic institutions (legal-person shares). Interestingly, employee ownership is negligible in Chinese PLCs. However, this formal ownership structure is somewhat misleading, since it does not clarify the nature of owners or trace the ultimate owners.

[Table 2 here]

Chinese law requires that the stakes of the largest ten shareholders are reported.

In Table 2, we classify their natures as a) another domestic industrial company; b) investment fund, securities companies and other investment firms; c) foreign investors; d) family or individual investors; e) government. ${ }^{3}$ Categories a) - d) together can be classified as the nongovernment shareholders. Using the data from the stock market, we seek to follow the methodology of La Porta, Lopez-de-Silanes, Shleifer (1999) in order to trace ultimate shareholders by examining pyramids, cross shareholdings and reciprocal shareholdings. The method defines a pyramid as an entry that has a shareholding in one PLC, which in turn owns another corporation and so on. Cross-shareholding are defined as a condition that exists when a company has a controlling shareholders and own shares in a firm that belongs to its chain of control, i.e. if A holds part of B and B holds part of A. Reciprocal shareholding occurs when a company owns part of itself. La Porta et al's (1999) weakest-link concept is adopted here i.e., if A hold 15 percent of B, and B holds 20 percent of C, then A holds 15 percent of C. .In our sample, 167 companies of the 846 reported that another PLC among the largest ten shareholders in 1998, with an average holding size of 1.5 percent. However, if we use a 10 percent threshold, only 19 firms are found to be pyramids or crossholdings, in the sense that an ultimate shareholder holds 10 percent of the company through another company.

In panel A of Table 2, we investigate the stakes of shareholding groups owning more than 50 percent, 30 percent and 10 percent of the equity respectively. These thresholds reflect majority ownership (50 percent); the CSRC measure of relative control (30 percent) and

\footnotetext{
${ }^{3}$ Non-government shareholders include institutional and individual shareholders. Institutional shareholders can be financial companies, foreign companies, collective holding entities, or other domestic industrial company such as PLCS or TVEs. Banks are forbidden to purchase and trade in PLCs, although in the past some have held shares. Investment trusts, mutual funds, and securities companies may also have some government ownership, but are now fully commercialized.
} 
Claessens et al's (2000) and Faccio and Lang's (2002) measure of the controlling threshold (10 percent). Significantly, the government as owner continues to play an important role in Chinese PLCs, quite out of line with that observed in other market or transition economies (see Bennett, Estrin and Maw, 2004). The state has a controlling (50 percent) interest in 31 percent of firms, and a large stake (10 percent) in a further 13 percent of firms. No other category of owner plays a comparable role, and the only other major category of shareholders is other domestic companies. ${ }^{4}$ While domestic companies hold more than at 10 percent stake in 41 percent of companies, almost as many as the state, their average shareholding is much lower and the category of domestic companies rarely has outright control (in less than 11 percent of Chinese PLCs).

Meanwhile, the ownership structure of Chinese PLCs is highly concentrated (see panel B of Table 2). The five largest shareholders account for 60.6 percent of equity, compared with 25.4 percent in the United States and 33.1 percent in Japan. The largest shareholder on average holds more than 40 percent of the equity. These high levels of ownership concentration are in part a consequence of the high levels of retained state ownership in Chinese PLCs.

In summary, Chinese PLCs are distinguished from their Western counterparts by the scale of government ownership and the concentration of ownership, both governmental and private. One can hypothesize a marked difference between the government as shareholder and non-government shareholders, characterized by the government's pursuit of its own political interests and its capacity for helping or harming the firm commercially in the process. In the following sections, we explore the nature of that difference at a theoretical and empirical level.

\section{Detrimental and beneficial effects of government shareholding}

Following the literature, we hypothesize that the government ownership is generally detrimental (see e.g. Vickers and Yarrow, 1988). That is, the firms with partial government ownership are expected to perform worse than those without any government ownership, and the

\footnotetext{
${ }^{4}$ In contrast to market economies, no individual in China can hold more than 0.5 percent of the shares of any company. This explains why this category is missing from the list of dominant shareholders. Rich Chinese families as owners must present themselves as private joint stock companies. For example, the largest shareholder of Orient Inc. Co. Ltd is the Orient Group, which, is registered as a joint-stock company. The entrepreneur, Zhang Hongwei, holds directly only 4.85 percent of this PLC and sits as the president of Orient Inc Co Ltd, but Mr. Zhang is the largest shareholder of the Orient Group. However, the ownership structure of an unlisted joint stock company is not released to the public. In this way, presenting themselves as an unlisted firm, rich families can circumvent the 5 percent limitation. Such events were very rare before 1998.
} 
firms under the dominant control of the government shareholder to perform worse than those under the control of a commercial shareholder. In this section, we develop a more comprehensive view of the government shareholder and argue that, under some circumstance, government shareholding may actually increase corporate value.

\section{A. Government shareholding is detrimental}

Shleifer and Vishny (1994) have modeled a typical emerging market environment in which joint stock companies are dominated by the government as shareholder; an owner that interferes in corporate activity by using its voting rights to influence business decisions. Political interference is usually at the expense of corporate profitability (see Boycko, Shleifer, and Vishny, 1996); for example, politicians may use their control to deliberately transfer resources of firms to their political supporters (Shleifer and Vishny, 1998). This suggests that government control of joint stock firms will be detrimental to corporate performance, a view confirmed empirically by Megginson and Netter (2001) for middle income countries and Djankov and Murrell (2002) for transition economies.

For example, the Sinopec Shanghai Petrochemical Company Limited, which has the government as majority shareholder, hired 38,000 employees for its core operation even though it did not need so many people. When it tried to lay off 17,000 employees, its government shareholder did not allow it to do so. Instead, the firm was forced to find jobs for its employees. It only succeeded in doing so for 13,000 of the employees it had originally planned to lay off, so it has had to pay the wages for the remaining 4,000. Although this satisfied the government shareholder's political interests, it was at the expense of corporate wealth.

In the context of a joint stock company, the extent to which the government shareholder may interfere in corporate activity in the pursuit of its political interests depends on the extent of its voting rights. Generally, as its voting rights increase, so does the extent of its interference. However, the likelihood and magnitude of political interference stops increasing once the shareholding stakes of the government have reached a certain size. We therefore hypothesize that the firms with partial government ownership perform worse than these with no government shareholding, and the firms under the control of a government shareholder perform worse than these under the control of a commercial shareholder. This issue is explored empirically in Sun 
and Tong (2003), who find a negative relation between the size of government shareholding and the market to book ratio, though this is only marginally significant at even the 10 percent level.

We would argue that, all else equal, the influence of the government on a firm in which the government shareholder owns 51 percent of shares is the same as that in a firm in which the government owns 85 percent. Hence once the controlling stake threshold, which varies with the specific shareholding structure of a company, has been passed, the probability and magnitude of political interference reach their maximum. Assigning the threshold as $\theta_{1}$, we argue that,

$$
\frac{\partial B}{\partial a}>0 \text { and } \frac{\partial V}{\partial B}<0 \text { if } a<\theta_{1}
$$

where $V$ is corporate value, $B$ is the private benefits from political interference and $a$ is the fraction of voting rights.

When $a>\theta_{1}, \frac{\partial B}{\partial a}=0$.

\section{B. The beneficial effect of government shareholding from corporate governance}

Megginson, Nash, and Van Randenborgh. (1994) establish that reducing or eliminating state ownership enhances performance by comparing corporate behavior before and after privatization. Comparing the performance of China's PLCs before with after issue privatization, Wang, $\mathrm{Xu}$, and Zhu. (2003), however, find that there is no significant improvement of corporate performance after share issue privatization. Wei, Varela, and D’Souza. (2003) further find that there is no improvement of corporate profitability, although they argue that, relative to the performance changes of fully state owned enterprises during the same period, listed firms relatively have better performance changes after privatization. Wang (2004) documents the sharp decline in post-issue operating performance of IPO firms, which suggests that reduction of government shareholding does not necessarily improve corporate performance.

However the government shareholder can be helpful to the firm in some circumstances. For example, to reduce managerial agency costs, a government-dominated shareholding structure is more effective than a dispersed shareholding structure under a weak legal enforcement. This point can be illustrated by the case of Monkey King Co. This firm, with no large shareholder to monitor its activities, manipulated its accounts and squandered its cash flows. This might have been prevented if there had been concentrated share ownership from any source, including the 
government. Corporate governance by the government shareholder may not be as strong as that of commercial shareholder but it exists and as Qian (2003) has stressed, the government has strong financial market interest in the successful performance of state owned firms. Thus it is unsurprising that the Chinese State Council has an explicit policy guideline to remove managers from firms under government control if they have been responsible for losses over three successive years.

If there is to be government-based corporate governance within a firm, the state's shareholding stake must be sufficiently large; if its voting rights are small, it is difficult for the government to control the managers. In addition, limited voting rights mean cash flow rights are also small, and since monitoring managers is costly, a government shareholder with small voting rights has weak incentives to do so. Naturally, as the size of the government's shareholding stake increases and the proportion of cash flow received by the government shareholder starts to outweigh the monitoring cost of the managers, the government shareholder has more incentive to provide corporate governance.

If we denote $G$ as the cost of corporate governance, we hypothesize, $\frac{\partial G}{\partial a}>0$ and $\frac{\partial V}{\partial G}>0$ when $a>\theta_{2} ; \frac{\partial G}{\partial a}=0$ when $a<\theta_{2}$.

\section{The beneficial effect of government shareholding from preferential treatment}

The deficiencies of the Chinese business environment, in which markets do not always operate openly or fairly, gives politicians the ability to provide firm with privileged access to resources (see e.g., Che and Qian, 1998). For Chinese PLCs, this means that the government shareholder is in a position to provide a wide range of preferential treatments. The partiality includes biased regulations when the government is regulator, preferential loans when the government is creditor, large orders for products when the government is a consumer and discounted sales of production when the government is a producer. For example, Fu-Tian Express Way Co received direct subsides from the government to the tune of $\$ 18 \mathrm{~m}$, which represented 58 percent of its profits, and Shenzhen Municipal Government has a special committee to assist associated PLCs in financial distress.

However, government partiality comes at the expense of the financial interests or even the political interests of the government. Therefore, the government has no incentive to provide 
such costly partiality to a firm in which its cash flow rights are small. Thus, the extent of preferential treatment provided by the government is correlated to its cash flow rights.

Thus $\frac{\partial S}{\partial a}>0$ and $\frac{\partial V}{\partial S}>0$ when $a>\theta_{3} ; \frac{\partial V}{\partial a}=0$ when $a<\theta_{3}$.

where $S$ denotes the cost of government partiality.

\section{Synergy of the grabbing hand and the helping hand}

Combining these arguments, we hypothesize that the relations between corporate performance and state ownership may therefore be more complex than simply negative and monotonic. One might instead expect that, while concentrated (dominant) private shareholding yields superior corporate performance to concentrated state ownership, as state shareholding increases the balance of disadvantage from state ownership would begin to be offset by the impact of the "helping hand" of the state and by concentrated state ownership. One would expect performance to be at its minimum in mixed enterprises, where neither private nor state owners have sufficient control rights to provide effective corporate governance to the firm. In such enterprises neither state nor private owners are dominant so managers may face conflicting objectives and demands and weaker corporate governance, which will lead to inferior performance.

Based on the behaviors of political predation, corporate governance, and preferential treatment, the utility function of the government shareholder is as follows:

$U=a \times V+B-G-S$

Subject to:

$0 \leq a \leq 1$

$V=V_{0}+V_{G}+V_{S}-V_{B}$

where $V_{0}$ is corporate value independent of $a, V_{G}$ is value changed by $G, V_{S}$ by $S, V_{B}$ by $B$.

Therefore

Set $\varphi<\theta_{2}$ and $\varphi<\theta_{3}$, when $\varphi<\theta_{1}, \quad$ get $\frac{\partial V}{\partial a}<0$;

Set $\psi>\theta_{2}$ and $\psi>\theta_{3}$, when $\psi>\theta_{1}, \quad$ get $\frac{\partial V}{\partial a}>0$;

where $\varphi<\psi$. 
The relation between corporate value and government shareholding will therefore negative and then positive after a threshold. This simplified model here does not differentiate between voting rights and cash flow rights because the one-share-one-vote system makes the separation of voting rights and cash rights in China marginal (see Tian, 2000).

\section{I11. The effects of government shareholding on corporate value}

In this section, we first specify the estimating equations before outlining our proxies for corporate value, government shareholding and the control variables. We go on to present the results of our empirical work in three stages; a comparison of entirely private firms and mixed ownership companies; a comparison of firms with government as the largest single shareholder against firms with private owners as the largest single shareholder; and finally an analysis of the impact of government shareholding (as a continuous variable) on corporate value. We conclude the section with a discussion of possible endogeneity in our empirical work.

\section{A. The estimation model and variables}

We explore the relation between corporate value and government shareholding using the following equation

$$
V_{i t}=c+\alpha \times \text { Government }_{i t}+\beta \times \text { Control }_{i t}+\varepsilon_{i t}
$$

(10) where $V$

continues to denote corporate value, Government is a measure of government shareholding and Control is a vector of control variables for firm i in year t. We use the simplified Tobin's Q and the return on assets (ROA) to approximate corporate value. Tobin's Q is an adjusted measure of the market value of the firm which we calculate as the sum of the market value of equity and book value of debt over the book value of total assets. ${ }^{5}$ This is complemented by the ROA as an indicator of profitability in case share prices fail to reflect the true value of firms in China because of market efficiency issues.

Three variables are used to proxy the impact of government ownership. Private captures the distinction between entirely private and mixed enterprises. If the government is a shareholder of an enterprise, private is assigned the value of unity; otherwise, private is unity. However, the influence of the government as owner may depend on whether the state has a controlling interest

\footnotetext{
${ }^{5}$ This avoids arbitrary assumptions about depreciation and inflation rates. Chung and Pruitt (1994) show the explanatory power of the simplified Q is at least 96.6 percent of Lindenberg and Ross’s (1981) Tobin’s Q.
} 
in the firm. There have been few instances of collaboration among other shareholders to counter the largest shareholder in China so perhaps the largest shareholder can be viewed as being in control. Prilarge is assigned the value of unity if the largest shareholder is the government; it is zero if a non-government shareholder has the largest stake. Finally, we consider government shareholding as the proportion of state-owned shares to total shares, denoted State. Given the possibility of a non-monotonic relation between Value and Government, State is entered into the estimating equation in linear and quadratic form as State $^{2}$.

Our specification of the control variables draws on the current literature in empirical corporate finance, though we are somewhat constrained by data availability for China's PLCs. Gomes and Novaes (1999) argue that the presence of a second large owner monitors the controlling shareholder and prevents tunneling of corporate wealth. They therefore predict that the existence of a second large owner will be associated with a high market value. Second is defined to take the value of one when there is a second shareholder (in addition to the controlling shareholder) with more than a 10 percent stake in a firm. We also use the Herfindhal index as a proxy of the shareholding concentration in some equations. However since this index is strongly correlated with government holdings, it is omitted in regressions, which include State. Finally, since Morck, Shleifer, and Vishny (1988) have established the importance of managerial ownership for Tobin's Q, we include the proportion of shares held by the top management team, denoted Manager.

We follow the finance literature in controlling for size in our corporate value equations. Large firms may have scale economies and better access to bank credits, which could improve corporate profitability (Chhibber and Majumdar, 1999). The asset structure or tangibility is also argued to influence corporate valuation. Tangibility is approximated by the fixed asset ratio; the net fixed assets over total assets. It is expected that the fixed asset ratio has a negative impact on corporate value, as firms with a high proportion of intangible assets tend to belong to the new economy. Since Titman and Wessels (1988) and Rajan and Zingales (1995) find that capital structure is correlated to ROA and market-to-book value we also control for gearing; total liabilities over total asset. Further, a large literature argues that, given the enterprise life cycle, the age of a firm will be related to corporate profitability and market value. In China, new firms tend to have a higher value because of the reform process. We also use year dummies to capture rapid institutional change and macroeconomic shocks in different years. 


\section{B. Empirical results}

We first compare the performance of the different categories of Chinese PLC by ownership type. The results confirm the negative impact of state ownership on corporate value. We go on to use regression analysis to estimate equation (1) on our data set using both OLS and panel data methods. These regressions confirm our previous results, establish their robustness with respect to specification and estimation method and indicate that the relation between corporate value and government ownership stakes is non-monotonic.

\section{B.1. Performance by ownership type in Chinese PLCs}

Our first set of tests on the impact of government ownership involves a comparison of means and medians of corporate value in sub-samples of the data set categorized by ownership type. This follows the method of Boardman and Vining (1989). We use Student t-tests to compare mean values, and given the possibility of outlier effects, also employ Mann-Whitney Utests to investigate the significance of median differences. ${ }^{6}$ Since we find no major difference between the results using the two methods, our reporting concentrates on mean differences, though both sets of tests are reported.

In columns (1) and (2) of Table 3, we compare corporate value in firms with no state holding (NSE) against enterprises with some state shareholding (MEs). In column (3) and (4), we compare firms where the largest shareholder is not the state (NSL) with firms with the state as largest shareholder (SL). Finally in column (5) and (6) we compare firms where the dominant owner ( $>50$ percent) is the state (Smaj) with firms where the dominant shareholder is not the state (NSmaj). Table 3 shows that enterprises with no state ownership perform significantly better than the category of all mixed enterprises. The mean of Q is 19 percent higher in entirely private than in mixed enterprises and the ROA is 18 percent higher. When we look at firms where the largest shareholder is private, we again find significant differences to state dominated firms in means and medians for both measures of corporate value. The shareholder with the largest stake is often the controlling shareholder in China, as there are few instances as yet of collaboration between smaller shareholders to counter the largest shareholder. If the government is the largest shareholder, Q decreases on average by 14 percent and ROA by 12 percent. When 
we group firms by whether the majority shareholder is the government, we find that $\mathrm{Q}$ is on average 25 percent higher and ROA is 37 percent where the majority shareholder is not the government.

\section{B.2. Multivariate analysis}

Our regression analysis is based on equation (1). We report the results of the pooled ordinary linear regressions adjusted by White robust estimators (OLS) and maximum log likelihood panel data estimation (MLP). OLS estimation with the robust standard errors produces consistent standard errors, even if the data is weighted or the residuals are not independently distributed. The F-statistics and R-squared are similar to the standard OLS estimations. Given that there may be concern about outliers, we also employ least-absolute value models (MAD models). Panel data models reduce the potential problem that omitted variables are correlated with explanatory variables. The cross-sectional OLS regression as the between estimator is less efficient because it discards the over-time information in the data in favor of simple means while model uses both the within and the between information. Our panel is unbalanced covering 287 firms in 1994 and 826 firms in 1998 and wide, the results of Baltagi-Li LM tests support the assumption of random effects. The maximum log likelihood estimation of the MLP model is consistent and asymptotically efficient for our data ${ }^{7}$. Therefore, the following model is estimated $y_{i t}=\alpha+x_{i t} \beta+v_{i}+\varepsilon_{i t}$

by maximizing the log likelihood of the ith unit

$$
\begin{aligned}
l_{i}= & -\frac{1}{2}\left\{\frac{1}{\sigma_{e}^{2}}\left[\sum_{t=1}^{T_{i}}\left(y_{i t}-x_{i t} \beta\right)^{2}-\frac{\sigma_{u}^{2}}{T_{i} \sigma_{u}^{2}+\sigma_{e}^{2}}\left(\sum_{t=1}^{T_{i}}\left(y_{i t}-x_{i t} \beta\right)\right)^{2}\right]\right. \\
& \left.+\ln \left(T_{i} \frac{\sigma_{u}^{2}}{\sigma_{e}^{2}}+1\right)+T_{i} \ln \left(2 \pi \sigma_{e}^{2}\right)\right\}
\end{aligned}
$$

In the regressions we take the distribution of government shares as a continuous variable with the results reported under the polynomial forms, but the piecewise regressions were also performed, with the same results.

[Table 4 here]

\footnotetext{
${ }^{7}$ Moulton (1986) shows that the standard errors of the OLS estimation for the one-way error component model with the unbalanced panel data set are biased. The GEE population-averaged panel data models are used to check the robustness of the MLP models. The results are very similar and the tables of the GEE models are not presented here.
} 
Table 4 presents the OLS and MLP regressions of equation (1) using private as the proxy for government ownership. The regressions have Q as dependent variable in columns (1) and (2), using OLS and MLP respectively, and ROA in column (3) and (4). In column 1, taking Q as the dependent variable, the coefficient of private is 0.242 with p-value below 5 percent. In column 3 , the coefficient of private is 0.006 with p-value below 5 percent. Multiplying the coefficients with the means of the corresponding variables, we find from columns (1) and (3) that the firms without any government shareholding outperform these with a government shareholder by 10.7 percent of $\mathrm{Q}$ and 10.6 percent of ROA in the robust OLS regressions. The results in MLP regressions are similar to those in the OLS regressions. Therefore, using the first large sample of mixed enterprises in China, we find that private enterprises perform better than mixed enterprises.

We next analyze the impact of the state owning a major interest on the firm on corporate value. This involves re-estimating equation (1) using prilarge as the proxy for the state ownership (Prilarge is zero if the government is the largest shareholder). Since Chinese PLC can have many shareholders, the government shareholder may need a controlling stake to influence performance. Hence the results in Table 5 represent a stronger test of the efficiency of government ownership than those of Table 4. Columns (1) and (2) take Q as the dependent variable using OLS and MLP methods respectively, while (3) and (4) use ROA. We find the coefficients on Prilarge are positive and significant in all four regressions. The mean of Q in the firms with the largest shareholder as the government is 7.7 percent lower in the OLS regression than in those with a non-government shareholder owning the largest stake. The coefficients of prilarge in columns 3 and 4, which take ROA as the dependent variables, are also significant and positive. The mean of ROA in the firms with the largest shareholder as the government is 7.8 percent lower than these with a non-government largest shareholder. This confirms the hypothesis that firms under the control of government as shareholder under-perform. Comparing Table 5 with Table 4, the decrease on coefficients of government shareholding probably arises because firms under the control of a non-government shareholder may still have a small government shareholder.

In our final experiment, we explore the relation between corporate value and the scale of government's shareholding stake directly by estimating a version of equation (1) in which government is proxied by the proportion of shares owned by the state. We also discuss in more detail the impact of the control variables on corporate value. 
Preliminary regressions were estimated on the assumption that the relation between corporate value and state was linear. Our findings confirmed others in the literature (see e.g. Chen, Firth, and Rui, 2000) in that no significant relation between corporate value and state was identified. However, as we argued in section 3, this may be because the relation between corporate value and the proportion of government shareholding is non-linear. This view is suggested by the raw data. For example, across the whole data set the average value of Q is 2.94 for firms with zero shareholding, 2.29 for firms with a 30 percent state share but 2.6 for firms with an 80 percent or more state share. Comparable figures for the ROA are 0.059, 0.04 and 0.059 respectively. In Table 6, we therefore report results for our estimates of equation (1) with $\mathrm{G}_{\mathrm{it}}$ being proxied by a quadratic in State. ${ }^{8}$ As before, columns (1) and (3) are OLS regressions and columns (2) and (4) are MLP regressions. We once again observe very little difference in the pattern of sign and significance between the two estimation methods for the main variables of interest. We employ the same proxies for corporate value; $\mathrm{Q}$ is columns (1) and (2) and ROA in column (3) and (4) and the pattern of results with respect to state ownership is similar between the two.

The coefficient on state is found to be significant and negative in all four regressions, while that of State $^{2}$ is positive and significant. Hence, corporate value decreases as the government's stake increases up to a threshold at around 30-40 percent, and then begins to increase. We draw the Chart for Tobin's Q based the OLS regressions in Figure 1 below.

Fig. 1

\footnotetext{
${ }^{8}$ We also experimented with spline regressions. We found both $\mathrm{Q}$ and ROA significantly decreased to a certain threshold and then increased significantly with the increased size of state.
} 


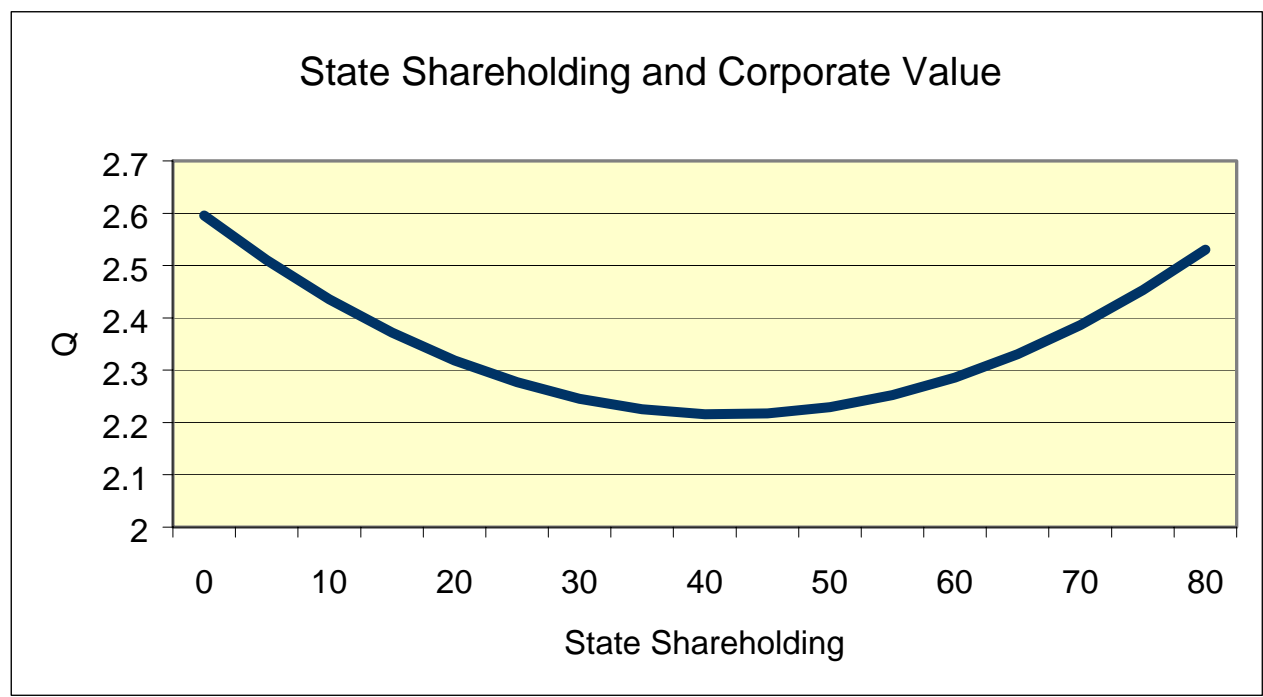

The turning points are found to be in the range of 30 percent to 40 percent, which interestingly represents the level at which it might be argued that the state has built a controlling interest in the firm.

Table 6 also provides a good model with which to explore the impact of the vector of control variables in corporate value. Commencing with the other ownership controls, the equations provides only limited support for the view that multiple large shareholders improve corporate value. The estimated coefficient on second is positive and significant in columns (1) and (2) but is not significant when we use ROA as the proxy for corporate value. This might be because minority shareholders benefit from the presence of multiple large shareholders, who reduce the private benefits of control and may facilitate takeovers. The tunneling behavior of the largest shareholder may also be better monitored. However, disagreements and bargaining between multiple large shareholders may also hinder efficient decision-making. Hence the market value may be high with multiple shareholders but their presence does not increase accounting profits or ROA.

Managerial ownership also has no significant association with Q but a positive impact on ROA. This may be because during the IPO period, the shares sold to employees and managers are priced at a significant discount. The initial managerial holding depends on the rationing of discounted shares and the personal budget constraints of these managers. The law forbids managers to trade shares when they are in office. Thus the sizes of managerial shareholding stakes do not signal the quality of firms. However, given that the shares comprise a significant 
part of the personal wealth of the manager, managers may have sharper incentives to maximize corporate profitability when their personal wealth is more aligned with corporate (see Jenson and Meckling, 1976). The signs for coefficients of size on Q are significant negative; large enterprises have a relatively low corporate value. This result is consistent with $\mathrm{Xu}$ and Wang (1999) and Qi et al. (2000). However, the size impact is significant and positive when regressing ROA on Size, which is consistent with Hall and Weiss (1967). This contradictory result may be due to the transitional nature of China's stock market. The positive sign of size on ROA suggests that larger firms may also be more difficult to restructure than smaller ones, which impact negatively on market to book values. The regressions confirm unambiguously however that the asset structure influences corporate value; firms with greater intangible assets are valued higher in all four specifications. We also find that higher debt is associated with a lower corporate value in China. This is consistent with findings for other developing countries (Rajan and Zingales, 1995; Booth, Aivazian, Demirguc-Kunt, and Maksimovic, 2001). Pecking order theory may explain this; only when the firms have no internal financing resources will they resort to borrowing, so firms with high earnings have low gearing ratios. This causality issue could complicate the models' specification, but in fact the results of the U-shaped pattern are robust to the removal of gearing ratios from the regressions.

We also find that firm age has a negative impact on corporate value, which is consistent with our prediction. The theory of path dependence suggests that old firms have more entrenched problems, which is reflected in lower profitability and market value. Finally, the signs of stock exchange dummy are negative and once significant (column (1). This suggests that, during 1994-1998, investors favored the Shenzhen Stock Exchange more than Shanghai. Comparing the stock index between 1994 and 1998 (see Table 1) we find the Shenzhen composite index rose 144.6 percent and Shanghai by 77.0 percent.

\section{Is government ownership endogenous?}

Our equations suggest that government shareholding influences corporate value in a nonmonotonic way. However, the results may be influenced by reverse causality if the government shareholding is determined by prior enterprise profitability. Moreover, since the government will benefit from an increase in corporate value, an understanding of the relation implied by equation (10) may lead to changes in ownership states. These factors suggest that government 
ownership stakes may be an endogenous variable in equation (10), bringing our findings into question if the simultaneity issue is not addressed.

To be precise, we must test for,

$$
\text { Government }_{i t}=c+\alpha \times V_{i t-1}+\beta \times \text { Control }_{i t}+\varepsilon_{i t}
$$

We therefore have a simultaneous equation system, when equation 13 is combined with equation 10. Table 7 uses two-stage least squares and limited information maximum likelihood methods to estimate the effect of government shareholding on corporate performance and therefore to capture the potential reverse causality. In the simultaneous equation system, corporate value and the size of government shareholding are jointly dependent variables. We take lagged corporate value, financial leverage, firm size, corporate age, and industrial sector dummies as the instruments.

In the first stage regression, the coefficients on lagged corporate value are always insignificant. Consistent with Wei, Xie, and Zhang (2004), this suggests that firm performance was actually not an important determinant of state ownership Chinese PLCs. Reporting the second stage regressions, Table 7 further confirms the findings of Table 6. The coefficients on State are positive and these on State ${ }^{2}$ are negative. The turning points remain around 30 percent. Even taking into account reverse causality, the main results of the previous sections remain unchanged. Perhaps this is not surprising because the Chinese government has always argued that its shares in PLCs were not sold for revenue purposes. The ideology of the communist party has been the driving force behind the privatization policy, not government revenue targets, and the declared objective behind selling state shares has been to restructure enterprises (see Measures on the Shareholding Experiment", State Council, 15 May 1992).

With regard to seasoned equity offerings, the central government encourages its agents that hold the state's shares to maintain their stake unchanged, and it does not allocate a sufficient budget for seasoned equities. The purchase of seasoned shares therefore depends on the budget constraints of the agents who hold state shares. In practice, changes in state ownership after the IPO have been small and are driven by political factors since the control rights of the government shareholder have almost always been diluted.

As for the block transfer of state shares, enterprise restructuring is again stipulated to be the target rather than privatization revenue. In several cases, the government has granted its shares to strategic investors. For example, in 1997 the government gave away for nothing its 
shares in Tianjin Meilun to Tianjin Taida Group Co. Transfers of state shares, including both grant transfers and negotiated transfers, usually work towards injecting new capital into the company and updating its technology rather than raising revenue (Securities Times, 2000).

Both the empirical evidence and the institutional arrangements therefore lead us to conclude that endogeneity of state ownership has not been a significant issue in Chinese PLCs during our data period. The non-monotonic relation between state shareholding and corporate value is found to reflect mainly causality from ownership to corporate value.

\section{Conclusions}

China continues to follow its own unique reform path, including in its "privatization" of the large former SOEs. The approach has been to sell shares in the companies, in the hope of inspiring performance via improved incentives, monitoring and corporate governance. However, the state has retained very significant shareholdings in many of these companies, though they are listed on the Chinese stock exchanges. In this paper, we have attempted to identify the scale and impact of state ownership on corporate performance in China.

Our results confirm findings in the literature for other economies that the overall impact of government shareholding is negative in China. However, in China's unique set of mixed ownership enterprises, the relation between the extent of government shareholding and corporate performance is complex. Our empirical work draws on a unique new data set of Chinese PLCs. We find that the detrimental effects of state shareholding is not monotonic but initially declines as the state retains some shares, up to a holding of between 30 percent and 40 percent, and increases thereafter. On average, state ownership reduced value by between 10 percent and 20 percent at the minimum, relative to entirely private firms. However, the negative impact of dominant state ownership is rather less; only around 5 percent. We argued that this might be because the efficiency of managerial decision making is reduced when managers have to balance the competing claims of large private and a large state shareholder. Moreover, in the Chinese context, the state has the power to distort outcomes in favor of the firms that it owns, and it has the incentive to do so when its shareholding stakes are high. In this sense, Chinese firms can benefit from a concentrated owner, whether that owner is private or the state.

This U-shaped relation between government ownership and corporate values therefore arises because the utility function of the government contains financial as well as political 
variables. The political interests of the government cause a reallocation of corporate resources, which is detrimental to a firm. But when it is pursuing the financial interests that lie in its cash flow rights, the government can provide some degree of effective corporate governance, depending on the size of its shareholding, and can act with benevolence and partiality. We infer that the value of a firm decreases as government shareholding stakes increase until a certain threshold, because when the government is a small shareholder, it has neither the authority nor the incentive to provide the preferential treatment and benevolence that would outweigh the disadvantages of its political interference. If the presence of a government shareholder is to be beneficial to a firm, its shareholding stakes must be relatively large.

\section{Appendix:}

Data Sources

Data Sources Reliability

Share price data $\quad$ Datastream Inc. $\quad$ Established International Renown

Data Specialist

Accountancy data Taiwan Economic The leading data specialist company

before IPO

Journal

in Taiwan and the major Chinese

data vendor to Reuters, Datastream

etc.

Accountancy data Genius Inc. More than 80 percent Chinese

after IPO

investment bankers and security

analysts rely on the data provided by 
this company.

State ownership Genius Inc.

Board of directors Taiwan Economic

Journal

Large shareholders Beijing Hairong Inc. The major financial data specialist company in Beijing.

Industrial China Securities Daily The leading newspaper on finance

classification and securities in China

Block transfer China Securities Daily

State-share transfer Securities Times A major newspaper on securities in China

With regards to accountancy and ownership data, the validity of the data sets has been crosschecked and missing points were made up based on annual reports form the website managed by the Shenzhen Stock Exchange. http://www.cninfo.com.cn/. 


\section{References}

Allen, Franklin, Qian, Jun, Qian, Meijun, 2004. “Law, finance, and economic growth in China.” Journal of Financial Economics, forthcoming.

Bennett, John, Estrin, Saul, Maw, James, 2004. "Mass privatisation and partial state ownership of firms.” Journal of the European Economic Association, forthcoming.

Blanchard, Olivier, Shleifer, Andrei, 2000. "Federalism with and without political centralization: China versus Russia.” NBER Working Paper No. w7616.

Booth, Laurence, Aivazian, Varouj, Demirguc-Kunt, Asli, Maksimovic, Vojislav, 2001. "Capital structures in developing countries.” Journal of Finance 56(1): 87-130.

Boycko, Maxim, Shleifer, Andrei, Vishny, Robert W., 1996. “A Theory of Privatization.” Economic Journal, 106(435), 309-19.

Che, Jiahua, Qian, Yingyi, 1998. "Insecure property rights and government ownership of firms,” Quarterly Journal of Economics, Vol. $113 \quad$ (2), 467, 30p.

Chen, Gong-Meng, Firth, Michael, Rui, Oliver, 2000. “Have China’s enterprise reforms led to improved efficiency and profitability for privatized SOEs?” Working Paper, Hong Kong Polytechnic University.

Chhibber, Pradeep, Majumdar, Sumit, 1999. "Foreign ownership and profitability: property rights, control and the performance of firms in Indian industry.” Journal of Law and Economics, 42 (1), 209-239.

Chung, Kee, Pruitt, Stephen, 1994. “A simple approximation of Tobin’s Q." Financial Management 23(3), 70-74. 
Chang, Chun, Wang, Yijiang, 1994. “The nature of the township-village enterprise.” Journal of Comparative Economics 19 (3), 434-453.

Claessens, Stijn, Djankov, Simeon, Lang, Larry, 2000. “The separation of ownership and control in East Asian Corporations. “ Journal of Financial Economics 58(1-2), 81-112.

Djankov, Simeon, Murrell, Peter, 2002. "Enterprise restructuring in Transition: A quantitative survey.” Journal of Economic Literature 40(3), 739-793.

Estrin, Saul, Perotin, Virginie, 1991. “Does Ownership always matter?” International Journal of Industrial Organization 9(1), 55-73.

Faccio, Mara, Lang, Larry, 2002. "The separation of ownership and control: an analysis of ultimate ownership in western European corporations.” Journal of Financial Economics 65(3), 365-395.

Gomes, Armando, Novaes, Walter, 1999. “Multiple large shareholders in corporate governance”. Working Papers, Wharton School Rodney L. White Center for Financial Research.

Hall, Marshall, Weiss, Leonard, 1967. "Firm size and profitability.” Review of Economics and Statistics 3, 319-332.

Jensen, Michael, Meckling, William, 1976. “Theory of the firm: managerial behavior, agency costs and ownership structure.” Journal of Financial Economics 3, 305-360.

La Porta, Rafael, Lopez-de-Silanes, Florencio, Shleifer, Andrei, 1999. “Corporate ownership around the world.” Journal of Finance 54(2), 471-517.

Lau, Lawrence, Qian, Yingyi, Roland, Gerard, 2000. "Reform without losers: An interpretation of China's dual-track approach to transition.” Journal of Political Economy 108(1), 120-142. 
Li, Wei, 1997. "The impact of economic reform on the performance of Chinese state enterprises, 1980-1989.” Journal of Political Economy 105(5), 1080-1106.

Lindenberg, Eric, Ross, Stephen, 1981. “Tobin’s q Ratio and industrial organization,” Journal of Business 54(1), 1-33.

Megginson, William, Nash, Robert, Van Randenborgh, Matthias, 1994. “The Financial and Operating Performance of Newly Privatized Firms: An International Empirical Analysis.” Journal of Finance 49, 403-452.

Megginson, William, Netter, Jeffry, 2001. "From state to market: a survey of empirical studies on privatization.” Journal of Economic Literature 39(2), 321-389.

Morck, Randall, Shleifer, Andrei, Vishny, Robert, 1988. "Management ownership and market valuation: an empirical analysis.” Journal of Financial Economics 20, 293-316.

Moulton, Brent, 1986. "Random group effects and the precision of regression estimates." Journal of Econometrics 32(3), 385-397.

Qi, Daqing, Wu, Woody, Zhang, Hua, 2000. "Shareholding structure and corporate performance of partially privatized firms: evidence from Listed Chinese companies.” Pacific-Basin Finance Journal 8(5), 587-610.

Qian, Yingyi, 2003. “How reform worked in China.” In: Rodrick, J. (Ed.), In Search of Prosperity, Chapter 11. Princeton University Press.

Rajan, Ranghuram, Zingales, Luigi, 1995. “ What do we know about capital structure? Some evidence from international data.” Journal of Finance 50(5), 1421-1460. 
Shleifer, Andrei, Vishny, Robert, 1994. "Politicians and Firms.” Quarterly Journal of Economics 109(4), 995-1025.

Shleifer, Andrei, Vishny, Robert, 1998. "The Grabbing Hand: Government Pathologies and Their Cures.” Cambridge, MA: Harvard University Press.

Sun, Qian, Tong, Wilson, 2003.” China Share Issue Privatization: The extent of its success.” Journal of Financial Economics 70, 183-222.

Tian, Guoqiang, 2000. "Property rights and the nature of Chinese collective enterprises.” Journal of Comparative Economics 28(2), 247-269.

Titman, Sheridan, Wessels, Roberto, 1988. “ The determinants of capital structure choice.” Journal of Finance 43(1), 1-19.

Vickers, John, Yarrow, George, 1988. "Privatization: An Economic Analysis”, Cambridge, MA: MIT Press

Wang, Changyun, 2004. "Ownership and operating performance of Chinese IPOs.” Journal of Banking and Finance, forthcoming.

Wang, Xiaozu, Xu, Lixin Colin, Zhu, Tian, 2004. "State-owned enterprises going public: The case of China." Economics of Transition 12(3), 467-488.

Wei, Zuobao, Varela, Oscar, D’Souza, Juliet, Hassan, Kabir, 2003. “The financial and operating performance of China’s newly privatized firms.” Financial Management, 32, 107-126.

Wei Zuobao., Xie, Feixue, Zhang, Shaorong, 2004. "Ownership structure and firm value in China’s privatized firms”. Journal of Financial Quantitative Analysis, forthcoming. 
$\mathrm{Xu}, \mathrm{Xiaonian}, \mathrm{Wang}, \mathrm{Yan}, 1999$. “Ownership structure and corporate governance in Chinese stock companies”. China Economic Review 10, 75-98. 
Table 1: Chinese Stock Market

This table presents the market capitalization over Chinese GDP, number of shareholders of the listed companies, number of listed companies, stock market indexes, turnover rates, and price/earning ratios. It covers a period from 1992 to 1998. The Chinese stock market is separated into the Shanghai Stock Exchange and Shenzhen Stock Exchange.

The market capitalization and the number of investors are the aggregated number from both the exchanges. Our data sources are the Shanghai Stock Exchange, Shenzhen

Stock Exchange, and China Securities Regulation Commission. Capitalization of Germany and UK equity markets are based on Bank of England, the factbook of the London Stock Exchange. The P/E ratio is from the Bloomberg system.

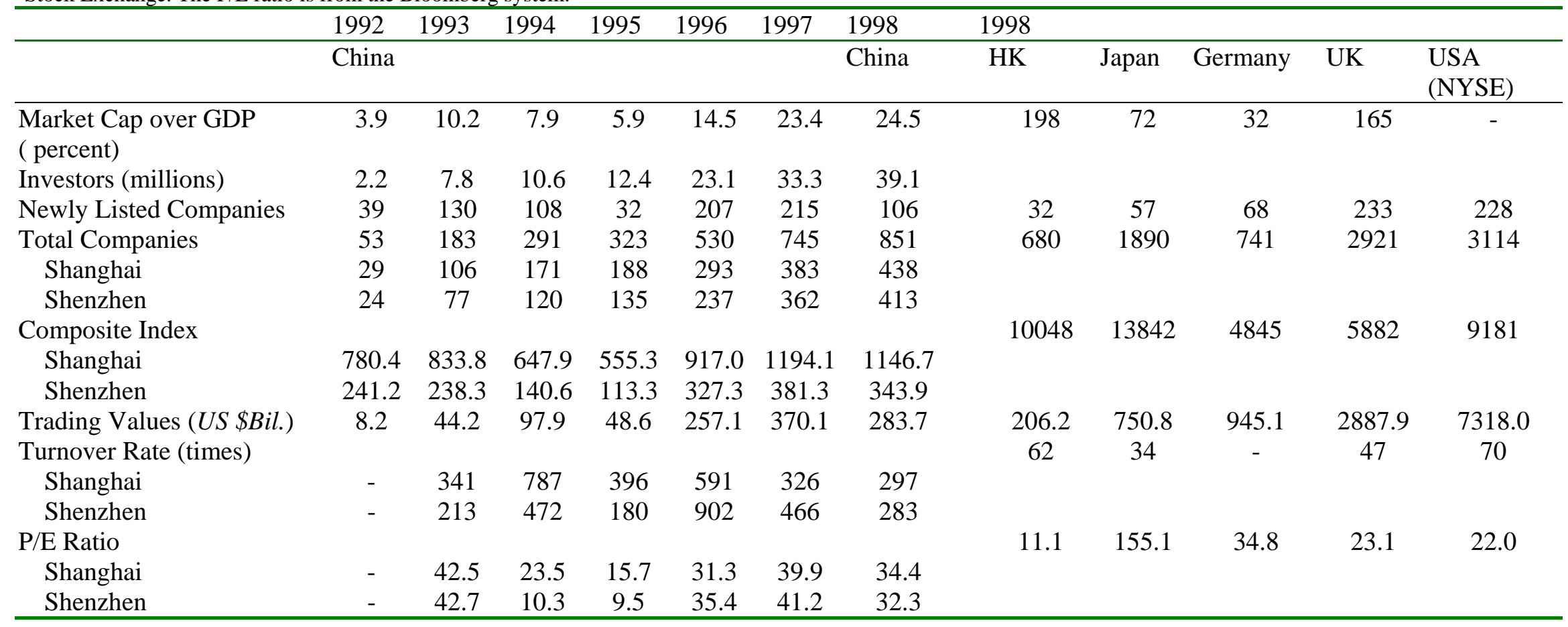


Table 2: Shareholding Structures of Chinese Quoted Firms

Panel A: Proportion of Companies with a Single Shareholding in Excess of 10 percent, 30 percent, or 50 percent

This table summarizes the proportion of companies with a large shareholder. Companies are divided into those that have one shareholder owning at least 10 percent, 30 percent, or 50 percent of the voting equity. It is based on the 1998 data of 826 companies. Data for firms in Hong Kong and Japan comes from Claessens, Djankov, and Lang (2000); Data for firms in the UK and Germany is from Faccio and Lang (2002).

\begin{tabular}{|c|c|c|c|c|c|c|c|c|}
\hline & \multirow[t]{2}{*}{ Largest shareholder } & \multirow[t]{2}{*}{50 percent } & \multirow[t]{2}{*}{30 percent } & \multirow{2}{*}{$\begin{array}{l}10 \\
\text { percent } \\
\text { China }\end{array}$} & \multicolumn{4}{|c|}{10 percent Cut-off } \\
\hline & & & & & HK & UK & Germany & Japan \\
\hline Another Domestic Company & 39.2 & 10.5 & 27.3 & 41.2 & 23.9 & 0.9 & 1.2 & 5.3 \\
\hline $\begin{array}{l}\text { Trust, Securities and Other Financial } \\
\text { Companies }\end{array}$ & 10.9 & 0.8 & 2.5 & 4.4 & 7.1 & 32.6 & 10.4 & 38.5 \\
\hline Foreign & 5.1 & 0.0 & 3.1 & 6.2 & - & - & - & - \\
\hline Family & 0.0 & 0.0 & 0 & 0 & 64.7 & 33.8 & 71.6 & 13.1 \\
\hline State & 43.9 & 31.4 & 37.8 & 43.8 & 3.7 & 0.2 & 5.2 & 1.1 \\
\hline Others & 0.8 & 0 & 3.8 & 2.4 & 0 & 6.3 & 7.2 & 0 \\
\hline $\begin{array}{l}\text { Companies without a large shareholding } \\
\text { greater than } 10 \text { percent, } 30 \text { percent, } 50 \\
\text { percent }\end{array}$ & & 57.2 & 25.4 & 2.1 & 0.6 & 26.2 & 4.40 & 42 \\
\hline Ratio of Cash Flow to Voting Rights & & & & 99.9 & 88.2 & 86.3 & 84.2 & 60.2 \\
\hline
\end{tabular}

Panel B: Shareholding fractions of the 10 largest shareholders

This table summarizes the average shareholding fractions of the ten largest shareholders in mixed enterprises, no-state-shareholding enterprises, enterprises with the government as the largest shareholder and enterprises with a non-government entity as the largest shareholder. $1^{\text {st }}$ is the largest, $2^{\text {nd }}$ is the second largest, and so on. The data apply to 826 firms in 1998.

\begin{tabular}{lcccccccccc}
\hline & 1st & 2nd & 3rd & 4th & 5th & 6th & 7th & 8th & 9th & 10th \\
\hline & & & & & & & & & & \\
Mixed Enterprises & 42.5 & 10.1 & 3.8 & 2.0 & 1.3 & 0.8 & 0.6 & 0.5 & 0.4 & 0.4 \\
Private Enterprises & 41.5 & 11.7 & 4.8 & 2.6 & 1.5 & 0.9 & 0.7 & 0.5 & 0.4 & 0.4 \\
Enterprises with government as the largest shareholder & 46.1 & 8.1 & 3.0 & 1.6 & 1.1 & 0.8 & 0.6 & 0.5 & 0.4 & 0.4 \\
Enterprises with a non-government largest shareholder & 40.1 & 12.3 & 5.0 & 2.7 & 1.6 & 0.9 & 0.7 & 0.5 & 0.4 & 0.4 \\
Total & 42.1 & 10.7 & 4.2 & 2.2 & 1.4 & 0.9 & 0.6 & 0.5 & 0.4 & 0.4 \\
\hline
\end{tabular}


Table 3: Comparing the Value and Characteristics of Firms

NSEs are enterprises with no state shareholding. NSLs are firms whose largest shareholder is not the state (non-state largest shareholder) and SLs are firms where the State is the largest shareholder. A NSmaj is an enterprise in which the major shareholder is a non-government entity. A Smaj is an enterprise in which the government holds more than 50 percent of shares. The asterisks show the range of $\mathrm{P}$ or $\mathrm{z}$-values: ${ }^{* * *}$ as $\mathrm{p}$ or $\mathrm{z}$-value $\leq 1$ percent, ${ }^{* *} \mathrm{p}$ or $\mathrm{z}$-value $\leq 5$ percent, * $\mathrm{p}$ or $\mathrm{z}$-value $\leq 10$ percent.

\begin{tabular}{|c|c|c|c|c|c|c|c|c|}
\hline & & (1) & (2) & (3) & (4) & (5) & (6) & (7) \\
\hline Items & & NSEs & MEs & NSL & SL & NSmaj & Smaj & All \\
\hline \multirow[t]{2}{*}{$\mathrm{Q}$} & Mean & 2.935 & $2.467 * * *$ & 2.817 & $2.457 * * *$ & 2.995 & $2.547 * * *$ & 2.604 \\
\hline & Median & 2.547 & $2.197 * * *$ & 2.450 & $2.190 * * *$ & 2.603 & $2.303^{* * *}$ & 2.291 \\
\hline \multirow[t]{2}{*}{ ROE } & Mean & 0.059 & $0.050 * * *$ & 0.056 & $0.050 * * *$ & 0.074 & $0.054 * * *$ & 0.053 \\
\hline & Median & 0.063 & $0.054 * * *$ & 0.063 & $0.054 * * *$ & 0.074 & $0.056 * * *$ & 0.058 \\
\hline Observations & & 778 & 1882 & 1089 & 1571 & 348 & 1028 & 2660 \\
\hline
\end{tabular}


Table 4: Does the government as shareholder influence value?

This table reports the regressions of $\mathrm{Q}$ in columns 1 and 2 and ROA in columns 3 and 4 on whether the government is a shareholder and whether the government is the largest shareholder. The table comprises 2660 firm-year observations. Private is the dummy variable that is zero when the government is a shareholder. Columns 1 and 3 reports the robust pooled OLS regression (OLS) and Columns 2 and 4 for the maximum log likelihood regressions (MLP). Standard deviations are given in brackets. The asterisks show the range of P-values: *** as pvalue $\leq 1$ percent, ** p-value $\leq 5$ percent, * p-value $\leq 10$ percent.

\begin{tabular}{|c|c|c|c|c|}
\hline & $(1)$ & $(2)$ & (3) & $(4)$ \\
\hline & OLS & MLP & OLS & MLP \\
\hline & $\mathrm{Q}$ & $\mathrm{Q}$ & ROA & ROA \\
\hline \multirow[t]{2}{*}{ Private } & $0.242^{\star \star}$ & $0.229 * * *$ & $0.006^{* *}$ & $0.005^{\star *}$ \\
\hline & $(0.077)$ & $(0.065)$ & (0.003) & $(0.003)$ \\
\hline \multirow[t]{2}{*}{ Second } & $0.114^{*}$ & $0.115^{\star}$ & -0.005 & -0.003 \\
\hline & (0.063) & $(0.066)$ & (0.003) & (0.003) \\
\hline \multirow[t]{2}{*}{ Manager } & 0.159 & 0.603 & $0.305^{\star \star \star}$ & $0.284^{* *}$ \\
\hline & (1.883) & (2.849) & $(0.069)$ & (0.144) \\
\hline \multirow[t]{2}{*}{ Herfindahl } & $6.452^{\star \star \star}$ & $9.362^{\star \star \star *}$ & $0.184^{\star \star \star}$ & $0.295^{\star \star *}$ \\
\hline & $(1.646)$ & $(2.034)$ & $(0.066)$ & $(0.090)$ \\
\hline \multirow[t]{2}{*}{ Size } & $-0.583^{\star *}$ & $-0.608^{\star \star *}$ & $0.029 * \star \star$ & $0.034^{* \star *}$ \\
\hline & $(0.062)$ & $(0.070)$ & $(0.004)$ & $(0.003)$ \\
\hline \multirow[t]{2}{*}{ Tangible } & -0.496 & -0.433 & -0.025 & -0.028 \\
\hline & (0.227) & (0.213) & (0.008) & (0.008) \\
\hline \multirow[t]{2}{*}{ Gear } & $-1.702^{\star \star *}$ & $-1.424^{\star \star \star}$ & $-0.164^{\star \star \star}$ & $-0.154^{\star \star \star}$ \\
\hline & $(0.355)$ & $(0.175)$ & $(0.025)$ & $(0.007)$ \\
\hline \multirow[t]{2}{*}{ Age } & $-0.004^{\star * \star}$ & -0.005 & $-0.0002^{\star \star \star}$ & $-0.0003^{*}$ \\
\hline & $(0.001)$ & $(0.002)$ & $(0.000)$ & $(0.000)$ \\
\hline \multirow[t]{2}{*}{ Exchange } & $-0.178^{\star \star}$ & -0.118 & -0.003 & -0.001 \\
\hline & $(0.052)$ & $(0.069)$ & $(0.002)$ & (0.003) \\
\hline Industry & Yes. & Yes. & Yes. & Yes. \\
\hline Year & Yes. & Yes. & Yes. & Yes. \\
\hline Constant & $\begin{array}{c}8.130 \star \star \star \\
(0.545)\end{array}$ & $\begin{array}{c}8.351 \text { *** } \\
(0.627)\end{array}$ & $\begin{array}{c}-0.110^{\star \star \star} \\
(0.029)\end{array}$ & $\begin{array}{c}-0.136 * \star \star \\
(0.025)\end{array}$ \\
\hline R-squared & 0.504 & -4357.9 & 0.427 & 4154.7 \\
\hline F statistic & 34.95 & 410.29 & 14.10 & 772.32 \\
\hline Significance & 0.000 & 0.000 & 0.000 & 0.000 \\
\hline
\end{tabular}


Table 5: Does the government as the largest shareholder affect value?

This table reports the regressions of Q in columns 1 and 2 and ROA in columns 3 and 4 on whether the government is the largest shareholder. The table comprises 2660 firm-year observations. Prilage is the dummy that is zero when a private agent is the largest shareholder. Columns 1 and 3 reports the robust pooled OLS regression (OLS) and Columns 2 and 4 for the maximum log likelihood regressions (MLP). Standard deviations are given in brackets. The asterisks show the range of $\mathrm{P}$-values: ${ }^{* * *}$ as $\mathrm{p}$-value $\leq 1$ percent, ${ }^{* *} \mathrm{p}$-value $\leq 5$ percent, ${ }^{*} \mathrm{p}$ value $\leq 10$ percent.

\begin{tabular}{|c|c|c|c|c|}
\hline Prilarge & $\begin{array}{c}(1) \\
\text { OLS } \\
Q \\
0.172^{\star \star \star} \\
(0.061)\end{array}$ & $\begin{array}{c}(2) \\
M L P \\
Q \\
0.161^{\star \star *} \\
(0.060)\end{array}$ & $\begin{array}{c}(3) \\
\text { OLS } \\
\text { ROA } \\
0.005^{\star *} \\
(0.003)\end{array}$ & $\begin{array}{c}(4) \\
M L P \\
Q \\
0.005^{\star \star} \\
(0.002)\end{array}$ \\
\hline Second & $\begin{array}{c}0.087 \\
(0.067)\end{array}$ & $\begin{array}{c}0.080 \\
(0.068)\end{array}$ & $\begin{array}{l}-0.005 \\
(0.003)\end{array}$ & $\begin{array}{l}-0.004 \\
(0.003)\end{array}$ \\
\hline Manager & $\begin{array}{c}0.413 \\
(1.868)\end{array}$ & $\begin{array}{c}0.825 \\
(2.852)\end{array}$ & $\begin{array}{c}0.310 * * * \\
(0.070)\end{array}$ & $\begin{array}{l}0.288^{\star *} \\
(0.113)\end{array}$ \\
\hline Herfindahl & $\begin{array}{c}6.513^{\star \star \star} \\
(2.067)\end{array}$ & $\begin{array}{c}9.426 * \star \star \\
(2.033)\end{array}$ & $\begin{array}{c}0.186 \star \star \star \\
(0.066)\end{array}$ & $\begin{array}{c}0.298 * \star \star \\
(0.091)\end{array}$ \\
\hline Size & $\begin{array}{c}-0.581^{* * *} \\
(0.062)\end{array}$ & $\begin{array}{c}-0.608 * * * \\
(0.070)\end{array}$ & $\begin{array}{c}0.030 * \star \star \\
(0.004)\end{array}$ & $\begin{array}{c}0.034^{\star * *} \\
(0.003)\end{array}$ \\
\hline Tangible & $\begin{array}{l}-0.493 \\
(0.226)\end{array}$ & $\begin{array}{l}-0.429 \\
(0.213)\end{array}$ & $\begin{array}{c}-0.025^{\star *} \\
(0.008)\end{array}$ & $\begin{array}{l}-0.028 \\
(0.008)\end{array}$ \\
\hline Gear & $\begin{array}{c}-1.721^{\star \star *} \\
(0.360)\end{array}$ & $\begin{array}{c}-1.434^{\star \star \star} \\
(0.175)\end{array}$ & $\begin{array}{c}-0.164^{\star \star *} \\
(0.025)\end{array}$ & $\begin{array}{c}-0.154^{\star * *} \\
(0.007)\end{array}$ \\
\hline Age & $\begin{array}{c}-0.005^{\star * *} \\
(0.001)\end{array}$ & $\begin{array}{l}-0.005 \\
(0.002)\end{array}$ & $\begin{array}{c}-0.0002^{* * *} \\
(0.000)\end{array}$ & $\begin{array}{c}-0.0003^{* *} \\
(0.000)\end{array}$ \\
\hline Exchange & $\begin{array}{c}-0.177^{\star \star} \\
(0.053)\end{array}$ & $\begin{array}{l}-0.120 \\
(0.070)\end{array}$ & $\begin{array}{l}-0.003 \\
(0.002)\end{array}$ & $\begin{array}{l}-0.001 \\
(0.003)\end{array}$ \\
\hline Industry & Yes. & Yes. & Yes. & Yes. \\
\hline Year & Yes. & Yes. & Yes. & Yes. \\
\hline Constant & $\begin{array}{c}8.109 * \star * \\
(0.551)\end{array}$ & $\begin{array}{c}8.353^{* * *} \\
(0.629)\end{array}$ & $\begin{array}{c}-0.111^{\star \star \star} \\
(0.029)\end{array}$ & $\begin{array}{c}-0.137^{\star * *} \\
(0.025)\end{array}$ \\
\hline $\begin{array}{l}\mathrm{R} \wedge 2 / \text { Log Likelihood } \\
\text { F/Chi^2 statistic } \\
\text { Significance }\end{array}$ & $\begin{array}{l}0.511 \\
34.83 \\
0.000\end{array}$ & $\begin{array}{c}-4360.6 \\
402.94 \\
0.000\end{array}$ & $\begin{array}{l}0.425 \\
14.08 \\
0.000\end{array}$ & $\begin{array}{c}4154.5 \\
771.82 \\
0.000\end{array}$ \\
\hline
\end{tabular}


Table 6: Polynomial regressions on the impact of state ownership

This table reports the regressions of $\mathrm{Q}$ and ROA on the fraction of government shareholding, using 2660 firm-year observations. State2 is the squared form of state shareholding (State). Panel 1 presents the results of the robust pooled OLS regression (OLS) and Panel 2 the maximum likelihood random effect panel model regression (MLP). Standard deviations are given in brackets. The asterisks behind the coefficient show the range of P-values: *** as $\mathrm{p}$-value $\leq 1$ percent, ${ }^{* *} \mathrm{p}$-value $\leq 5$ percent, $* \mathrm{p}$-value $\leq 10$ percent.

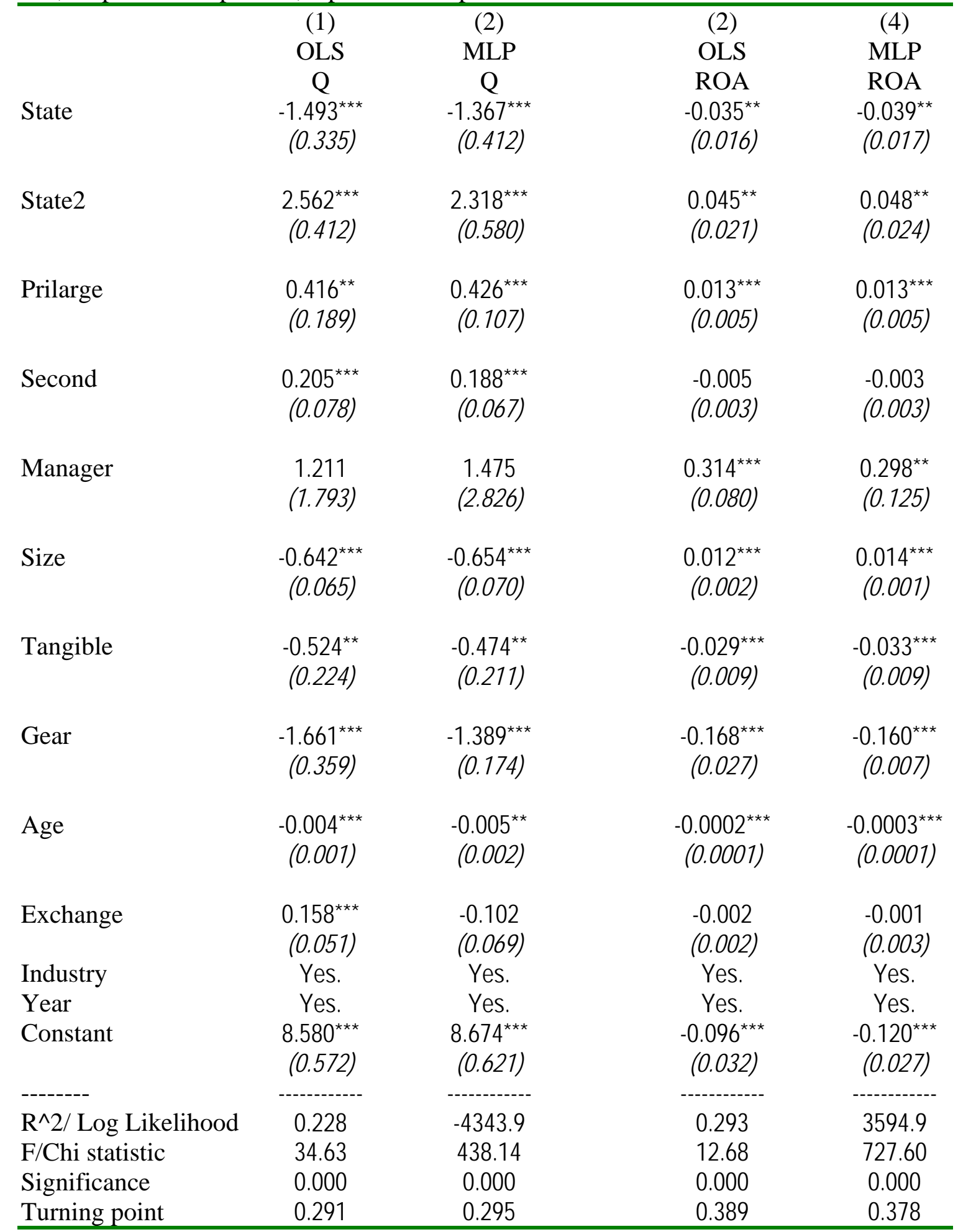


Table 7: Instrumental variable regressions on the state shareholding

This table reports the regressions of $\mathrm{Q}$ and ROA on the fraction of government shareholding, using 2660 firm-year observations. State2 is the square of state shareholding (State). The robust clustered two stage least square regression (2SLS) and the limited information maximum likelihood regression (LIME) are reported here. The size of government shareholding, state, is instrumented on lagged Q or ROA, financial leverage, firm size, corporate age, industrial sector dummies. Standard deviations are given in brackets. The asterisks behind the coefficient show the range of P-values: $* * *$ as $\mathrm{p}$-value $\leq 1$ percent, $* *$ p-value $\leq 5$ percent, $*$ p-value $\leq 10$ percent.

\begin{tabular}{|c|c|c|c|c|}
\hline & $(1)$ & $(2)$ & $(2)$ & $(4)$ \\
\hline & $2 S L S$ & LIME & 2SLS & LIME \\
\hline & $\mathrm{Q}$ & $\mathrm{Q}$ & ROA & ROA \\
\hline \multirow[t]{2}{*}{ State } & $-1.399 * \star \star$ & $-1.407^{\star * *}$ & $-0.027^{\star}$ & $-0.032^{*}$ \\
\hline & $(0.372)$ & $(0.337)$ & $(0.015)$ & $(0.018)$ \\
\hline \multirow[t]{2}{*}{ State2 } & $2.099 * * *$ & $2.109 * * *$ & $0.042^{*}$ & 0.056 ** \\
\hline & $(0.446)$ & $(0.394)$ & $(0.024)$ & $(0.024)$ \\
\hline \multirow[t]{2}{*}{ Prilarge } & 0.008 & 0.007 & 0.002 & 0.003 \\
\hline & (0.064) & (0.071) & $(0.006)$ & $(0.004)$ \\
\hline \multirow[t]{2}{*}{ Second } & $0.133^{\star *}$ & $0.133^{\star \star *}$ & -0.005 & $-0.007 * *$ \\
\hline & (0.058) & $(0.045)$ & $(0.004)$ & $(0.003)$ \\
\hline \multirow[t]{2}{*}{ Manager } & $-3.175^{\star *}$ & $-3.181^{\star *}$ & $0.325^{\star \star \star}$ & $0.377^{* * *}$ \\
\hline & $(1.369)$ & (1.602) & $(0.110)$ & $(0.098)$ \\
\hline \multirow[t]{2}{*}{ Size } & $-0.295^{\star \star \star}$ & $-0.295^{\star \star \star}$ & $0.013^{\star * *}$ & $0.003^{\star *}$ \\
\hline & $(0.034)$ & $(0.022)$ & $(0.002)$ & $(0.001)$ \\
\hline \multirow[t]{2}{*}{ Tangible } & -0.146 & -0.146 & $-0.025^{\star *}$ & $-0.023^{\star \star *}$ \\
\hline & $(0.170)$ & (0.128) & $(0.010)$ & $(0.008)$ \\
\hline \multirow[t]{2}{*}{ Gear } & $-0.924^{\star \star \star}$ & -0.921 & $-0.164^{\star \star *}$ & $-0.149 * \star *$ \\
\hline & $(0.153)$ & $(0.104)^{\star \star \star}$ & $(0.026)$ & $(0.006)$ \\
\hline \multirow[t]{2}{*}{ Age } & -0.002 & -0.002 & $-0.000 * *$ & -0.000 ** \\
\hline & (0.001) & (0.001) & $(0.000)$ & $(0.000)$ \\
\hline \multirow[t]{2}{*}{ Exchange } & -0.017 & -0.017 & -0.003 & $-0.006^{\star *}$ \\
\hline & $(0.050)$ & (0.036) & $(0.003)$ & $(0.002)$ \\
\hline Industry & Yes. & Yes. & Yes. & Yes. \\
\hline Year & Yes. & Yes. & Yes. & Yes. \\
\hline \multirow[t]{2}{*}{ Constant } & $8.067 * \star *$ & $8.074^{\star \star *}$ & $-0.106^{\star \star *}$ & $0.073^{\star * *}$ \\
\hline & $(0.729)$ & $(0.457)$ & $(0.036)$ & $(0.028)$ \\
\hline $\mathrm{R}^{\wedge} 2$ & 0.317 & 0.317 & 0.286 & 0.242 \\
\hline F/Chi statistic & 30.26 & 1217 & 12.23 & 836 \\
\hline Significance & 0.32 & 0.32 & 0.29 & 0.24 \\
\hline Turning point & 0.333 & 0.334 & 0.321 & 0.286 \\
\hline
\end{tabular}




\section{DAVIDSON INSTITUTE WORKING PAPER SERIES - Most Recent Papers}

The entire Working Paper Series may be downloaded free of charge at: www.wdi.bus.umich.edu

CURRENT AS OF 2/9/05

\begin{tabular}{|c|c|c|}
\hline Publication & Authors & Date \\
\hline $\begin{array}{l}\text { No. 750: Retained State Shareholding in Chinese PLCs: Does } \\
\text { Government Ownership Reduce Corporate Value? }\end{array}$ & Lihui Tian and Saul Estrin & Feb. 2005 \\
\hline No. 749: Financial Development and Technology & Solomon Tadesse & Feb. 2005 \\
\hline No. 748: Banking Fragility and Disclosure: International Evidence & Solomon Tadesse & Feb. 2005 \\
\hline $\begin{array}{l}\text { No. 747: Consolidation, Scale Economies and Technological Change in } \\
\text { Japanese Banking }\end{array}$ & Solomon Tadesse & Feb. 2005 \\
\hline $\begin{array}{l}\text { No. 746: Trade Creation and Diversion Effects of Europe’s Regional } \\
\text { Liberalization Agreements }\end{array}$ & Yener Kandogan & Feb. 2005 \\
\hline No. 745: Quality of Institutions, Credit Markets and Bankruptcy & Christa Hainz & Feb. 2005 \\
\hline $\begin{array}{l}\text { No. 744: How Transition Paths Differ: Enterprise Performance in Russia } \\
\text { and China }\end{array}$ & Sumon Bhaumik and Saul Estrin & Jan. 2005 \\
\hline $\begin{array}{l}\text { No. 743: Inflation Targeting, Between Rhetoric and Reality. The Case } \\
\text { of Transition Economies }\end{array}$ & Daniel Daianu and Laurian Lungu & Jan. 2005 \\
\hline $\begin{array}{l}\text { No. 742: How Does Law Affect Finance? An Empirical Examination of } \\
\text { Tunneling in an Emerging Market }\end{array}$ & $\begin{array}{l}\text { Vladimir Atanasov, Conrad S. } \\
\text { Ciccotello, \& Stanley B. Gyoshev }\end{array}$ & Jan. 2005 \\
\hline $\begin{array}{l}\text { No. 741: Do Insider Trading Laws Matter? Some Preliminary } \\
\text { Comparative Evidence }\end{array}$ & Laura Nyantung Beny & Jan. 2005 \\
\hline $\begin{array}{l}\text { No. 740: Autopsy on an Empire: Understanding Mortality in Russia and } \\
\text { the Former Soviet Union }\end{array}$ & $\begin{array}{l}\text { Elizabeth Brainerd and David M. } \\
\text { Cutler }\end{array}$ & Jan. 2005 \\
\hline $\begin{array}{l}\text { No. 739: Not Separate, Not Equal: Poverty and Inequality in Post- } \\
\text { Apartheid South Africa }\end{array}$ & $\begin{array}{l}\text { Johannes G. Hoogeveen and Berk } \\
\text { Özler }\end{array}$ & Jan. 2005 \\
\hline $\begin{array}{l}\text { No. 738: The Marketing Structure in Agribusiness during the Transition } \\
\text { in Bulgaria }\end{array}$ & $\begin{array}{l}\text { Steve Murray, Yordan Staykov, } \\
\text { and Valentin Katzerov }\end{array}$ & Jan. 2005 \\
\hline No. 737: Passive Creditors & $\begin{array}{l}\text { Koen Schoors and Konstantin } \\
\text { Sonin }\end{array}$ & Jan. 2005 \\
\hline $\begin{array}{l}\text { No. 736: From a currency board to the euro: Public attitudes toward } \\
\text { unilateral euroization in Bulgaria }\end{array}$ & Neven T. Valev & Jan. 2005 \\
\hline No. 735: Dictators and Their Viziers: Agency Problems in Dictatorships & $\begin{array}{l}\text { Georgy Egorov and Konstantin } \\
\text { Sonin }\end{array}$ & Jan. 2005 \\
\hline $\begin{array}{l}\text { No. 734: Foreign Investment, Corporate Ownership, and Development: } \\
\text { Are Firms in Emerging Markets Catching Up to the World Standard? }\end{array}$ & $\begin{array}{l}\text { Klara Sabirianova, Jan Svejnar, } \\
\text { and Katherine Terrell }\end{array}$ & Jan. 2005 \\
\hline $\begin{array}{l}\text { No. 733: Businessman Candidates: Special-Interest Politics in Weakly } \\
\text { Institutionalized Environments }\end{array}$ & $\begin{array}{l}\text { Scott Gehlbach and Konstantin } \\
\text { Sonin }\end{array}$ & Dec. 2004 \\
\hline $\begin{array}{l}\text { No. 732: Measuring the Institutional Change of the Monetary Regime } \\
\text { in a Political Economy Perspective }\end{array}$ & $\begin{array}{l}\text { Nikolay Nenovsky and Yorgos } \\
\text { Rizopoulos }\end{array}$ & Dec. 2004 \\
\hline $\begin{array}{l}\text { No. 731: Impact of Regulated Price Adjustments on Price Variability in } \\
\text { a Very Low Inflation Transition Economy: Case of Armenia }\end{array}$ & Aghassi Mkrtchyan & Nov. 2004 \\
\hline $\begin{array}{l}\text { No. 730: Reform, FDI and Economic Growth: Tale of the Tortoise and } \\
\text { the Hare }\end{array}$ & $\begin{array}{l}\text { Bruno Merlevede and Koen } \\
\text { Schoors }\end{array}$ & Nov. 2004 \\
\hline $\begin{array}{l}\text { No. 729: The Effects of Transition and Political Instability On Foreign } \\
\text { Direct Investment Inflows: Central Europe and the Balkans }\end{array}$ & $\begin{array}{l}\text { Josef C. Brada, Ali M. Kutan, } \\
\text { and Taner M. Yigit }\end{array}$ & Nov. 2004 \\
\hline $\begin{array}{l}\text { No. 728: Institutional Distance and International Business Strategies } \\
\text { in Emerging Economies }\end{array}$ & $\begin{array}{l}\text { Delia Ionascu, Klaus E. Meyer, } \\
\text { and Saul Erstin }\end{array}$ & Nov. 2004 \\
\hline No. 727: Explaining Patterns of Corruption in the Russian Regions & $\begin{array}{l}\text { Phyllis Dininio and Robert W. } \\
\text { Orttung }\end{array}$ & Nov. 2004 \\
\hline $\begin{array}{l}\text { No. 726: The Politics of Institutional Learning and Creation: Bank } \\
\text { Crises and Supervision in East Central Europe }\end{array}$ & Gerald A. McDermott & Nov. 2004 \\
\hline $\begin{array}{l}\text { No. 725: International Business and Development Economics: A } \\
\text { Winning Combination }\end{array}$ & Tamir Agmon & Nov. 2004 \\
\hline $\begin{array}{l}\text { No. 724: Importing High-Risk Capital and Revealing Hidden } \\
\text { Comparative Advantages }\end{array}$ & Tamir Agmon & Oct. 2004 \\
\hline $\begin{array}{l}\text { No. 723: Which entrepreneurs expect to expand their businesses? } \\
\text { Evidence from survey data in Lithuania }\end{array}$ & $\begin{array}{l}\text { Ruta Aidis and Tomasz } \\
\text { Mickiewicz }\end{array}$ & Oct. 2004 \\
\hline
\end{tabular}

